\title{
The Influence of Green Culture and Green Strategy on the Circular Economy Implementation: The Moderating Role of Green Intellectual Capital
}

\author{
Muafi \\ Department of Management, Business \& Economic Faculty, Universitas Islam, Sleman 558283, Indonesia
}

Corresponding Author Email: muafi@uii.ac.id

https://doi.org/10.18280/ijsdp.160611

Received: 4 August 2021

Accepted: 10 October 2021

\section{Keywords:}

green culture, green strategy, circular economy implementation, green intellectual capital

\begin{abstract}
This study aims to analyze the relationship between Green Culture (GC) and Green Strategy (GS) on the Circular Economy (CE) implementation. It also aims to analyze the moderating tole of Green Intellectual Capital (IC) on the relationship. The type of this study is quantitative research, and the data is collected through questionnaire. The respondents of this study are the owner or manager, or owner and manager of Batik MSMEs in Klaten, Central Java Province. The respondents are chosen purposively with certain criteria. The data is analyzed using Moderated Regression Analysis (MRA). The results of this study found that GC and GS partially influence the $\mathrm{CE}$ implementation. Green IC cannot moderate the relationship between GC and the CE implementation, but on the contrary, Green IC is able to moderate the influence of GS on the CE implementation.
\end{abstract}

\section{INTRODUCTION}

Circular economy (CE) currently becomes a strategic and interesting issue to be discussed. $\mathrm{CE}$ is a development of a linear economy (LE). Previously, LE emphasizes on the aspect of product use and disposal by taking into account the presence of waste. It is commonly known that the purchase of products by the public so far has been assessed with economic and social costs which generally lack a high concern for the environment. However, the environment should be maintained and cared for in order to remain sustainable. Over time, some business actors have started to realize and pay attention to the environmental aspects. Products and services that have been produced must be reprocessed though reduce, reuse, recycle, replace, and repair; thus, the concept of CE emerges [1]. The $\mathrm{CE}$ concept is created so that the business process and economic activity can survive in the long term by focusing on a commitment to have a high concern for the environment. The implementation of $\mathrm{CE}$ can have an impact on sustainable business and social activity in the long term [2] as well as increasing the company competitive advantage [3]. Each business activity unit is expected to be able to create useful value and increase the resilience of the products produced by the company [3-5]. Wijkman and Skånberg [3], MacArthur [4] added that $\mathrm{CE}$ is a restorative or regenerative industry system that must be followed with strong intention and design. The main consideration is that instead of throwing away the product before its value is fully utilized, it should be used and reused. The resources used must be really efficient. It is also added by Kirchherr et al. [5] that CE can be done by reducing, reusing, and improving resources in the process of production, distribution, and consumption, and it can be implemented in every level, both micro, meso, and macro.

In the micro level, particularly in MSMEs, long-term business sustainability in the CE practice is still rarely found in Asia, especially in Indonesia. However, a number of practitioners try to keep carrying out continuous learning to adopt greening behavior in every activity of their organizations, from the upstream to downstream activities. This is because several companies have realized the importance of protecting the environment [6-8]. When the CE concept is developed, it has to be understood as a way to improve the economic performance without having to consume resources at a rate that exceeds the earth's capacity [9]. CE must utilize various efficiency, productivity, and strategies, and be restoratively-oriented (circular strategy) in order to maintain the products, components, and materials to be able to be used longer. In fact, the current CE adoption and sustainable strategy carried out by the industry is still simple and has a little progress [9]. A number of research have proved that when companies implement green culture (GC) well, it can have positive impact on business sustainability [10-15], especially on environmental performance [10]. Others also proved that green strategy (GS) can have an impact on business sustainability [6, 16-19]. And ecological behavior [20, 21]. Unfortunately, in the context of MSMEs, the adoption of green strategy is still very limited [22-24].

This study is conducted in Batik MSMEs in Klaten which has been using natural dyes. The use of natural dye is based on the consideration from the owners or managers that it is for the reasons of the preservation of the natural environment. The resources for natural dye used are basic materials from wood and leaves. However, during their implementation in the field, it turned out that the Batik MSMEs experienced several obstacles, such as human resources, capital, technology, infrastructure, and other obstacles. Therefore, CE implementation needs to be reviewed by focusing on the importance of green culture (GC) and green strategy (GS) that have an impact on $\mathrm{CE}$ implementation and the moderating role of Green IC. This also becomes a trigger to fill the research 
gaps, and at the same time becomes the novelty of this study, especially in the context of Batik MSMEs that have implemented business processes by considering natural dye.

\section{LITERATURE REVIEW}

\subsection{Circular economy}

Currently, CE becomes an interesting issue to be studied and researched. This is because there are more academics and practitioners that have begun to gradually implement business practices both in the micro, meso, and macro level [5]. The micro level includes products, companies, and consumers. The meso level includes eco-industrial parks, while the macro level includes city, region, nation, and beyond. The CE concept becomes popular in the 1970s, as it was inspired by Rachel Carson's Silent Spring from the Club of Rome, which aims to reduce inefficient resources. This concept is increasingly developing and being implemented with different concepts and objectives both in the context of industry players and consumers [25], for example for sustainable development [5, 26]. In the context of CE, MacArthur focuses more on attracting stakeholders' attention to an approach that places more emphasis on environmental conditions, especially on material design and flow assessment. Meanwhile, UNEP defines $\mathrm{CE}$ as a concept which uses a green economy approach that aims to reduce the carbon economy [1]. On the other hand, [27] stated that CE is only 'a theoretical discourse in a dream', since it is very difficult to implement in the real world. In the future, managers will be faced with the challenge to improve practical and realistic implementation of sustainable development in the business context that is constantly changing. This is because it is very difficult to apply the triple bottom line (economic, social, and environmental) approach simultaneously. The findings from [5] confirmed that CE is most often described as a combination of reduce, reuse, and recycle, and that it is rarely discussed with regard to systemic shifts. The main goal of CE is economic prosperity, followed by goals for environmental quality. However, its impact on social justice and future generations is rarely discussed.

Potting et al. [28] introduced the 9R framework and divided the CE strategy into three groups, started by the linear economy process approach to $\mathrm{CE}$, namely: (1) useful application of materials (recover/R9 and recycle/R8); (2) extend lifespan of product and its parts (repurpose/R7, remanufacture/R6, refurbish/R5, repair/R4, reuse/R3); and (3) smarter product use and manufacture (reduce/R2, rethink/R1, refuse/R0). Kirchherr et al. [5] concluded that CE is an economic system that is based on the business model that replace the concept of 'the end' by reducing with the aims to achieve sustainable development, which have an implication on the environmental quality, economic prosperity, and social equity for present and future generations. It can be done by environmentally-friendly technological innovation [29]. In a $\mathrm{CE}$ framework for action, there are several areas that can be intervened, such as innovative product design, reverse cycles, green internal operations, supplier engagement, internal alignment, and external collaboration. All of these areas are recommended for companies when intervening to achieve business sustainability in a long term [30]. This requires the support from organizational culture, environmental analysis (company, industry, and external environment), as well as a business strategy that is integrated with the company's vision and mission based on the CE approach [30].

\subsection{Green culture and CE implementation}

The issue of greening is a crucial problem in the context of increasing $\mathrm{CE}$ implementation in Indonesia, especially in the context of SMEs [31]. It is undeniable that there are a number of empirical studies that emphasize the impact of organizational culture on economic benefits, but there are only a few that relate it to environmental adoption [9]. MSMEs are currently required to have a culture of innovation in every activity of their business processes, including a culture of green innovation. From an organizational perspective, the role of organizational culture is important for improving business sustainability in terms of business, social, and environmental performance [11, 32-34]. On the other hand, García-Machado and Martínez-Ávila [35] added that has a significant impact on environmental performance.

The role of all managers and employees is required in creating a new ecosystem that is oriented towards achieving business sustainability [12, 14]. Küçükoğlu and Pinar [11] even found that GC can improve business sustainability and organizational innovation. MSMEs must have a responsibility to be able to create green work environment and employee attitudes and behaviors that can eventually be realized into a green culture. All of them can be integrated with Green HRM strategies and policies [6, 7, 11]. Renwick et al. [36] emphasized that the cognition of love for the environment is very important to increase green values. It is also added by Liu and Lin Lin [10] that GC has an impact on environmentally friendly organizational behaviors. This means that GC can make a significant contribution on the $\mathrm{CE}$ implementation. The CE implementation should be a part of management practices that cover all systems, including organizational culture so that it can improve the achievement of GC behavior [15]. CE has a potential to increase management resources and facilitate decision making through the stages of industrial life cycle of the company assets. The $\mathrm{CE}$ implementation can be done by: (1) reinvent and rethink; (2) restore, reduce, and avoid; and (3) recirculate [9]. In addition, Sharma et al. [37] recommended that in order to create GC, textile industry managers can generate green innovation and green performance through the development of environmental awareness among employees, so that it can be used to reduce pollution. It should also be noted that organizational culture can be both a driver and an obstacle for companies to implement CE [38, 39].

\section{H1. GC has a significant positive influence on $C E$ implementation.}

\subsection{Green Strategy (GS) and CE implementation}

Green strategy (GS) currently becomes focus and receives attention from many companies in the micro, meso, and macro level. The European New Industry Strategy and European Green Deal have become the references for various parties in each level to be able to comprehensively apply GS $[9,40,41]$. The improvement of strategic implementation has experienced a positive increase [24, 42], although it is done gradually [5]. When a company carried out the environmental, health, and safety (EHS) integration, the company has automatically willing to increase their business sustainability [43]. Das and Singh [44], Velazquez et al. [45] recommended that 
commitment from the management is required when a company wants to implement GS comprehensively. The implementation of GS needs to receive support from many parties because it will have an impact on the improvement of CE implementation $[9,45,46]$. GS must be followed up with guidelines and policy making that is related to the principles of business sustainability [47]. Both technical and nontechnical strategy and policy is needed so that all operations can work efficiently to increase savings in the future [48]. Tonelli and Cristoni [30] even recommended the importance for companies to have management strategy approach to increase $\mathrm{CE}$ implementation in the company.

Several organizations have started to position that environmental quality attributes are one of the business strategies and competitiveness they offered [46]. Green strategy (GS) becomes one of the strategies of the company, so that they have a high concern for the environment in increasing ecological behavior [20] and can be used to increase competitive advantage [49-51]. Vargas-Hernández and LópezLemus [52] also found the result that companies that implement CE practices in environmental management can increase their competitive advantage through the achievement of competitive strategies, namely cost advantage and differentiation. Tjahjadi et al. [53] added that choosing and implementing green innovation strategy can have a significant impact on business performance. The results from the study conducted by Olayeni et al. [16] also showed that GS can increase environmental and financial performance.

\section{H2. GS has a significant positive influence on CE implementation.}

\subsection{The moderating role of green intellectual capital}

Companies are required to pay attention to not only tangible assets, but also to intangible assets. Intellectual capital (IC) is one of the intangible assets that must be managed and maintained as optimally as possible. A'yuni and Muafi [54], Huang and Kung [55] asserted that IC must be based on a knowledge economy in which knowledge is the benchmark for the organization can continue to move forward in the long term. The scope of IC is the total capability, knowledge, culture, strategy, processes, intellectual property, and relational networks in companies that can increase the company's value and competitive advantage [54, 56]. Huang and Kung [55], Firmansyah [56] stated that Green HC includes the expertise, capabilities, knowledge, experience, wisdom, innovation, creativity, and commitment of the employee towards the environment. Green $\mathrm{HC}$ is an indispensable process [42, 55, 57]. $\mathrm{HC}$ is a crucial aspect in the Green HRM practices in which the recruiting and selecting stage the organization requires applicants to have consideration of the greening aspect [8, 58]. When IC is associated with the natural environment, it can be referred to as Green IC [59, 60]. Yong et al. [6], A'yuni and Muafi [54], Chen [57], Muafi et al. [61], Chen and Chang [62] classified Green IC into 3 aspects, namely green human capital (GHC), green structural capital (GSC), and green relational capital (GRC). Companies must own Green IC because it will allow them to have high competitiveness [57] and increase their performance [62]. GSC is related to the company architecture to maintain, design, strengthen, and transfer knowledge during business activities in the company [63]. GSC is a set of organizational capabilities, organizational commitment, knowledge management system, reward system, information technology system, database, managerial mechanism, operational processes, managerial philosophy, organizational culture, corporate image, patents, copyrights, and trademarks related to environmental protection [54, 57]. On the other hand, GRC is a total interactive relationship of the company with the customer, supplier, network members, and business partners related to concern for environmental management and green innovation $[6,54,64]$. The research results from [9] found that business analytics capability can increase CE implementation and eventually has an impact on firm performance. The moderating role of IC has also been proven by Nemiño and Gempes [65] who recommended to consider company reputation and knowledge sharing while reviewing the platform and business policy formulation with the moderating role of IC. The results from Melani and Kusuma [66] also concluded that IC can strengthen the relationship between growth opportunities and financial performance. Likewise, Iqbal et al. [67] added that IC can have a function to moderate the relationship of CSR on company performance. These findings indicate that IC can act as moderator for a relationship between variables.

\section{H3. Green IC moderates the influence of $G C$ on $C E$ implementation. \\ H4. Green IC moderates the influence of $G S$ on $C E$ implementation}

\section{METHOD}

The type of this study is a quantitative study with positivism approach which aims to understand the relationship between variable $[68,69]$. This study uses survey with questionnaire as the data collection design. When the respondents experience difficulties in answering, the researcher provides contact and guides them one by one to provide understanding.

This study is carried out in Bayat, Klaten Regency, Central Java Province. The focus of the research is in the Batik MSMEs in two villages, namely Kebon and Banyuripan villages. These two villages have Batik MSMEs that is oriented to natural dyeing process instead of using synthetic colors. The population of this study is all owners, managers, and owners who also act as managers in the two villages. This study is limited to Batik MSMEs that uses natural dye because it is adapted to the research scheme, especially with the CE implementation. The population and target sample of this study is 250 MSMEs. This target sample has met the criteria for survey research [69]. The sampling technique is using proporsional area ramdom sampling, which is conducted by two steps. The first step is done by taking proportional samples in each area according to the target sample that has been determined. In each area, the sample taken is 125 MSMEs. On the second step, purposive sampling is carried out according to the number of known sample size. The criteria are as follows: (1) using natural dye for batik coloring that is obtained from leaves and roots; (2) have minimum employees of 3 person; and (3) have high school as latest education. After it is identified and screened, there are 200 respondents who met the requirement and provided complete answer. Therefore, the data can be processed further since it is able to represent the population.

This study uses 4 variables, namely GC, GS, Green IC, and $\mathrm{CE}$ implementation. Likert scale is used to provide answer choices for the variables for the respondents, ranging from 5 (strongly agree) to 1 (strongly disagree). Moderated regression 
analysis (MRA) is used as the statistical technique, which is done using SPSS 16 software. The measurement of the variables is sourced from:

1. GC (X1) uses 5 items modified from Ref. [10, 11].

2. GS (X2), uses 5 items modified from Ref. [16, 53].

3. Green IC (Z) uses 5 items modified from Ref. [6, 69].

4. CE implementation (Y) uses 8 items modified from Ref. [9].

The results of the validity and reliability test indicate that all items and variables are valid and reliable. The test for hypothesis 1 and 2 in this study is carried out using simple regression analysis. The test for hypothesis 3 and 4 is done using Moderated Regression Analysis (MRA).

\section{RESULT}

\subsection{Respondent description}

The majority respondent of this study is owners and managers of Batik MSME (77\%), female (93\%), have senior high school education (56\%), the MSME has been operating for at least 3 years $(86 \%)$, and have at least 3 employees $(87 \%)$. For further details, it can be seen on Table 1 .

\subsection{Hypothesis test}

The results of the hypothesis test is presented in Table 2 .

Table 2 shows that hypothesis 1, 2, and 4 is accepted, while hypothesis 3 is rejected. More details are explained as follows:

1. There is an influence of GC on CE implementation with the sign of 0.000 . This means that the more GC increases, the more CE implementation also increases with the $\mathrm{R}$ square value of 0.438 (43.8\%) (H1 accepted).

2. There is an influence of GS on CE implementation with sign of 0.027 . This means that the more Gs increases, the more $\mathrm{CE}$ implementation also increases with the $\mathrm{R}$ square value of $0.024(2.4 \%)$ (H2 accepted).

3. There is a moderating role of Green IC on the relationship between $\mathrm{GC}$ and $\mathrm{CE}$ implementation with the sign of 0.000 . It can be seen that the $\mathrm{R}$ square value in the first regression is $0.438(43.8 \%)$. On the second regression, after the moderation, the $\mathrm{R}$ square value becomes $0.305(30.5 \%)$. Thus, it can be concluded that Green IC cannot strengthen the relationship between $\mathrm{GC}$ and $\mathrm{CE}$ implementation (H3 rejected).

4. There is a moderating role of Green IC on the relationship between GS and $\mathrm{CE}$ implementation with the sign of 0.000 . It can be seen that the R square value in the first regression is $0.024(2.4 \%)$. On the second regression, after the moderation, the $\mathrm{R}$ square value becomes $0.070(7 \%)$. Thus, it can be concluded that Green IC can strengthen the relationship between GS and CE implementation (H4 accepted).

Table 1. Respondents' characteristics

\begin{tabular}{|c|c|c|c|}
\hline No & Age & Frequency & Percentage \\
\hline 1 & Ownership/Management & & \\
\hline & Owner & 30 & $15 \%$ \\
\hline & Manager & 16 & $8 \%$ \\
\hline & Owner and manager & 154 & $77 \%$ \\
\hline 2 & Gender & & \\
\hline & Male & 14 & $7 \%$ \\
\hline & Female & 186 & $93 \%$ \\
\hline 3 & Level of Education & & \\
\hline & Junior High School & 86 & $43 \%$ \\
\hline & Senior High School & 112 & $56 \%$ \\
\hline & Bachelor & 2 & $1 \%$ \\
\hline 4 & Length of Operation & & \\
\hline & $\leq 2$ years & 28 & $14 \%$ \\
\hline & $\geq 3$ years & 172 & $86 \%$ \\
\hline 5 & Number of Employee & & \\
\hline & 3 people & 174 & $87 \%$ \\
\hline & $\geq 4$ people & 26 & $13 \%$ \\
\hline & Total & 200 & $100 \%$ \\
\hline
\end{tabular}

Table 2. Results of hypothesis test

\begin{tabular}{|c|c|c|c|c|c|c|}
\hline Regression equation model & $\mathrm{R}^{2}$ & Constanta & Coeffisients (beta) & $\mathrm{t}$ & Sign & Note \\
\hline $\mathrm{H} 1 . \mathrm{Y}=\mathrm{a}+\mathrm{b} 1 \mathrm{X} 1+\mathrm{e}$ & 0.438 & 0.611 & 0.662 & 12.425 & $0.000^{*}$ & $\mathrm{H} 1$. accepted \\
\hline $\mathrm{H} 2 . \mathrm{Y}=\mathrm{a}+\mathrm{b} 1 \mathrm{X} 2+\mathrm{e}$ & 0.024 & 3.727 & 0.156 & 2.227 & $0.027^{*}$ & $\mathrm{H} 2$. accepted \\
\hline $\mathrm{H} 3 . \mathrm{Y}=\mathrm{a}+\mathrm{b} 1 \mathrm{X} 1+\mathrm{b} 2 \mathrm{Z}+\mathrm{b} 3 \mathrm{X} 1 \mathrm{Z}+\mathrm{e}$ & 0.305 & 2.731 & 0.552 & 9.313 & $0.000^{*}$ & H3. rejected \\
\hline $\mathrm{H} 4 . \mathrm{Y}=\mathrm{a}+\mathrm{b} 1 \mathrm{X} 2+\mathrm{b} 2 \mathrm{Z}+\mathrm{b} 4 \mathrm{X} 2 \mathrm{Z}+\mathrm{e}$ & 0.070 & 3.731 & 0.265 & 3.865 & $0.000^{*}$ & H4. accepted \\
\hline
\end{tabular}
Note $=$ *sign $<0.05$

\section{DISCUSSION}

The results of this study concluded that there is an influence of $\mathrm{GC}$ on $\mathrm{CE}$ implementation. It indicates that the more positive GC in the work environment of Batik MSMEs in Klaten, the more it can increase CE implementation. These results support the previous study and theory from Ref. [11, 32-34]. Batik MSMEs in Klaten need to create a green culture in their work environment. This is important considering that if MSMEs can create a greening-based ecosystem in each of their business activities, it will be easier for $\mathrm{CE}$ implementation, thus they will be able to improve business sustainability both from the aspect of business, environmental, and social $[12,14]$. Although it is not easy, the steps in creating the ecosystem can be done in stages, so that it will increasingly give a positive impression and attitude from employees and managers. This finding also strengthens the research results from [10] who recommended the importance of having environmentally-friendly organizational behaviors, especially for the managers and employees of MSMEs. When MSMEs have a positive attitude, it will be realized on the GC behavior [15]. When CE has been carried out well, Batik MSMEs will be able to implement their greening behavior in three important points, namely: (1) reinvent and rethink; (2) restore, reduce, and avoid; and (3) recirculate.

It is proven that it can be implemented successfully by Batik MSMEs in Klaten by utilizing natural dye that does not cause pollution and waste. Batik business that uses natural dye is proven to be able to survive until now in the midst of the competition between synthetic batik product from both 
regional and foreign competitors. However, it still requires a strong intention and commitment from the owners and managers of natural dye Batik MSMEs, because the future challenge is that they must be able to own and produce green IC in the organization. The results do not prove that Green IC can strengthen the relationship between $\mathrm{GC}$ on $\mathrm{CE}$ implementation (H3 rejected). It strengthens the research findings that Batik MSMEs have limitation in the aspect of human resources, especially the one that has a relation to Green IC. It should be noted that Green IC must be owned by MSMEs since organization will always move forward and must face the dynamically changing business demands that is volatile and hostile. When the capability and knowledge regarding greening behavior increases, it will be able to improve business sustainability and competitive advantage of the organization in the long term [54-56].

The findings of this study show that GS has a significant positive influence on $\mathrm{CE}$ implementation ( $\mathrm{H} 2$ accepted). It indicates that the more positive GS implemented by Batik MSMEs in Klaten, the more it is able to increase CE implementation. This supports the results from the previous studies such as Ref. [16, 20, 52, 53]. Batik MSMEs need to implement GS which must be integrated with the program, policy, and budget they owned. When Batik MSMEs have high concern towards the environment, they will be able to increase the reputation and ecological behavior of the employee [20]. Consequently, Batik MSMEs will have a strategic behavior that is realized in the policy making and strategic decision regarding strategic choice and implementation by having a cost advantage, or even differentiation if necessary. This is because CE implementation can increase the efficiency and cost advantage in each of the business activity. Sharma et al. [37] even recommended that when MSMEs can conduct $\mathrm{CE}$ implementation efficiently, they will be able to reduce the pollution in the environment. However, it still needs support and role of Green IC in order to strengthen the relationship between GS and CE implementation. The results of this study proves that Green IC can strengthen the relationship between GS and CE implementation (H4 accepted). It supports the previous researches which stated that IC can be a strong moderator to enhance organizational performance $[38,39,65]$. Green IC must be owned by Batik MSMEs because it can improve competitive advantage in the long term [57, 62].

\section{CONCLUSIONS}

The conclusion of this study are as follows:

1. There is a significant positive influence of GC toward $\mathrm{CE}$ implementation. Therefore, the more GC increases, the more it can improve $\mathrm{CE}$ implementation.

2. There is a significant positive influence of GS toward CE implementation. Therefore, the more GS increases, the more it can improve $\mathrm{CE}$ implementation.

3. IGC is unable to strengthen the relationship between $\mathrm{GC}$ on $\mathrm{CE}$ implementation.

4. IGC is unable to strengthen the relationship between GS on CE implementation.

\section{LIMITATION AND RECOMMENDATION \\ FUTURE \\ RESEARCH}

The limitation and future research recommendations from this study are as follows:

1. The respondent in this study is chosen only based on purposive sampling technique, thus it is feared that it cannot generalize the research population as a whole, especially in Klaten area, which has different community characteristics from the aspects of greening habits and behavior.

2. All of the questionnaire is conducted by selfevaluation and self-report; thus, subjectivity issue becomes one of the concerns since the respondents assess themselves without being asked to compare with their competitors of similar MSMEs.

3. Batik MSMEs respondent should first be given an understanding of the $\mathrm{CE}$ implementation because it will have an effect on their way of answering the questionnaire given. Therefore, when the questionnaire is distributed, the respondents can understand its meaning and substance well.

4. There is a need to consider other variables that affect CE implementation such as business capability [9], environmental uncertainty [64, 70], and IT adoption [70].

5. There are other moderating variables that should also be considered such as green lifestyle [71-73] and leadership agility [70, 74].

\section{REFERENCES}

[1] Purwanti, I. (2021). Konsep Dan Implementasi Ekonomi Sirkular Dalam Program Bank Sampah (Studi Kasus: Keberlanjutan Bank Sampah Tanjung). Jurnal Manajemen dan Ekonomi, 4(1): 83-92.

[2] Ghisellini, P., Cialani, C., Ulgiati, S. (2016). A review on circular economy: The expected transition to a balanced interplay of environmental and economic systems. Journal of Clean Production, 114: 11-32. https://doi.org/10.1016/j.jclepro.2015.09.007

[3] Wijkman, A., Skånberg, K. (2016). A study report at the request of the Club of Rome with support from the MAVA Foundation. The Circular Economy and Benefits for Society Jobs and Climate Clear Winners in an Economy Based on Renewable Energy and Resource Efficiency A study pertaining to The Czech Republic and Poland, pp. 1-59. https://circulareconomy.europa.eu/platform/sites/default /files/the-circular-economy-czech-republic-andpoland.pdf

[4] MacArthur, E. (2014). Towards the Circular Economy: Accelerating the scale-up across global supply chains. World Econ. Forum, 1-64.

[5] Kirchherr, J., Reike, D., Hekkert, M. (2017). Conceptualizing the circular economy: An analysis of 114 definitions. Resources, Conservation \& Recycling, 127: 221-232. https://doi.org/10.1016/j.resconrec.2017.09.005

[6] Yong, J.Y., Yuliza, M.Y., Olawole, F. (2019). Nexus between green intellectual capital and green human resource management. Journal of Cleaner Production, 
215:

$364-374$

https://doi.org/10.1016/j.jclepro.2018.12.306

[7] Arqawi, S., Zaid, A.A., Jaaron, A.A.M., Al hila, A.A., Al Shobaki, M.J., Abu-Naser, S.S. (2019). Green human resource management practices among Palestinian manufacturing firms- an exploratory study. Journal of Resources Development and Management, 52: 62-29.

[8] Al Romeedy, B.S. (2019). Green human resource management in Egyptian travel agencies: constraints of implementation and requirements for success. Journal of Human Resources in Hospitality \& Tourism, 18(4): 529548. https://doi.org/10.1080/15332845.2019.1626969

[9] Kristoffersen, E., Mikalef, O., Blomsma, F., Li, J.Y. (2021). The effects of business analytics capability on circular economy implementation, resource orchestration capability, and firm performance. International Journal of Production Economics, 239: 108205. https://doi.org/10.1016/j.ijpe.2021.108205

[10] Liu, X., Lin Lin, K. (2020). Green organizational culture, corporate social responsibility implementation, and food safety. Front Psychology, 11: 585435. https://doi.org/10.3389/fpsyg.2020.585435

[11] Küçükoğlu, M.T., Pinar, R.I. (2018). The mediating role of green organizational culture between sustainability and green innovation: A research in Turkish companies. Business and Management Studies, an International Journal, 6: 64-85. https://doi.org/10.15295/v6i1.208

[12] Li, J., Yu, D. (2018). The path to innovation: the antecedent perspective of intellectual capital and organizational character. Frontiers in Psychology, 9. https://doi.org/10.3389/fpsyg.2018.02445

[13] Wang, C.H. (2019). How organizational green culture influences green performance and competitive advantage the mediating role of green innovation. Journal of Manufacturing Technology Management, 30(4): 666683. https://doi.org/10.1108/JMTM-09-2018-0314

[14] Uslu, T. (2015). Innovation culture and strategic human resource management in public and private sector within the framework of employee ownership. Procedia - Social and Behavioral Sciences, 195: 1463-1470. https://doi.org/10.1016/j.sbspro.2015.06.445

[15] Claver, E., López, M., Molina, J., Tarí, J. (2007). Environmental management and firm performance: A case study. Journal of Environmental Management, 84(4): 606-619. https://doi.org/10.1016/j.jenvman.2006.09.012

[16] Olayeni, A., Ogbo, A., Okwo, H., Chukwu, B., Ifediora, C., Ezenwakwelu, C. (2021). Green strategy effect on financial and environmental performance: A mediation analysis of product quality. Sustainability, 13(4): 2115. https://doi.org/10.3390/su13042115

[17] Phoochinda, W., Kriyapak, S. (2021). Electronic waste recycling business: Solution, choice, survival. International Journal of Sustainable Development and Planning, 16(4): 693-700. https://doi.org/10.18280/ijsdp.160409

[18] Ullah, M.M., Jahan, S. (2017). The 'green' roles of hr professionals: green human resource management perspective. The Cost and Management, 45(2), MarchApril, 33-41.

[19] Hendra, J. (2013). Strategi Manajemen Lingkungan Dalam Rangka Penurunan Kandungan Limbah Bahan Berbahaya Dan Beracun (B3) Pt. Pindo Deli, Karawang, Jurnal Green Growth dan Manajemen Lingkungan, I(2): 74-83.
[20] Ar, I.M. (2012). The impact of green product innovation on firm performance and competitive capability: The moderating role of managerial environmental concern. Procedia - Social and Behavioral Sciences, 62: 854-864. https://doi.org/10.1016/j.sbspro.2012.09.144

[21] Angga, L.O., Akyuwen, R.J., Laturette, A.I., Daties, D.R.A., Tuhulele, P., Labetubun, M.A.H., Taufik, I. (2021). Responsibilities of industry actors to environmental conservation in coastal areas. International Journal of Sustainable Development and Planning, $16(4)$ : 651-660. https://doi.org/10.18280/ijsdp.160405

[22] Singh, Sanjay Kumar, Giudice, M.D., Chierici, R., Graziano, D. (2020). Green innovation and environmental performance: The role of Green transformational leadership and Green Human Resource Management. Technological Forecasting and Social Change, 150 : 119762. https://doi.org/10.1016/j.techfore.2019.119762

[23] Muafi, Uyun, Q. (2021). The effect of green HRM on business sustainability with the mediation role of proenvironmental behavior. Quality - Access to Success. 22(183): 163-170.

[24] Muafi, Uyun, Q. (2021b). Green HRM (GHRM) and business sustainability: The mediation role of environmental management strategy (EMS). Quality Access to Success, 22(182): 133-137.

[25] Winans, K., Kendall, A., Deng, H. (2017). The history and current applications of the circular economy concept. Renewable and Sustainable Energy Reviews, 68: 825833. https://doi.org/10.1016/j.rser.2016.09.123

[26] Murray, A., Skene, K., Haynes, K. (2017). The circular economy: An interdisciplinary exploration of the concept and application in a global context. Journal of Business Ethics, 140(3): 369-380. https://doi.org/10.1007/s10551015-2693-2

[27] Naudé, M. (2011). Sustainable development in companies: Theoretical dream or implementable reality? Corporate Ownership \& Control, 8(4-3): 352-364.

[28] Potting, J., Hekkert, M., Worrell, E., Hanemaaijer, A. (2017). Circular economy: Measuring innovation in the product chain. Policy Report. BL Netherlands Environmental Assessment Agency, the Hague. https://www.pbl.nl/sites/default/files/downloads/pbl2016-circular-economy-measuring-innovation-inproduct-chains-2544.pdf.

[29] Marino, A., Pariso, P. (2016). From linear economy to circular economy: Research agenda. International Journal of Research in Economics and Social Sciences, 6225(6): 2249-7382.

[30] Tonelli, M., Cristoni, N. (2019). Strategic Management and the Circular Economy. by Routledge 52 Vanderbilt Avenue, New York, NY 10017.

[31] Syafri, W., Prabowo, H., Nur, S.A., Muafi, M. (2021). The impact of workplace green behavior and green innovation on green performance of SMES: A case study in Indonesia. Journal Of Asian Finance, Economics and Business, 8(5): 365-374.

[32] Hanifah, H., Halim, H. A., Ahmad, N. H., Zadeh, A.V. (2019). Innovation Culture as a Mediator Between Specific Human Capital and Innovation Performance Among Bumiputera SMEs in Malaysia. Handbook of Research on Small and Medium Enterprises in Developing Countries, IGI Global. 
[33] Dobni, C.B. (2008). Measuring innovation culture in organizations: The development of a generalized innovation culture construct using exploratory factor analysis. European Journal of Innovation Management, 11(4): 539-559. https://doi.org/10.1108/14601060810911156

[34] Simpson, P.M., Siguaw, J.A., Enz, C.A. (2006). Innovation orientation outcomes: The good and the bad. Journal of Business Research, 59(10-11): 1133-1141. https://doi.org/10.1016/j.jbusres.2006.08.001

[35] García-Machado, J.J., Martínez-Ávila, M. (2019). Environmental performance and green culture: The mediating effect of green innovation. An application to the automotive industry. Sustainability, 11(18): 4874.

[36] Renwick, D.W., Redman, T., Maguire, S. (2013). Green human resource management: A review and research agenda. International Journal of Management Reviews, 15(1): 1-14. https://doi.org/10.1111/j.14682370.2011.00328.x

[37] Sharma, S., Prakash, G., Kumar, A., Mussada, E.K., Antony, J., Luthra, S. (2021). Analysing the relationship of adaption of green culture, innovation, green performance for achieving sustainability: Mediating role of employee commitment. Journal of Cleaner Production, 303(4). https://doi.org/10.1016/j.jclepro.2021.127039

[38] Ekins, P., Domenech, T., Drummond, P., Bleischwitz, R., Hughes, N., Lotti, L. (2019). The circular economy: What, why, how and where". Background paper for an OECD/EC Workshop on 5 July 2019 within the Workshop Series "Managing Environmental and energy transitions for regions and cities", Paris.

[39] AMEC Environment \& Infrastructure and Bio Intelligence Service. (2013). The opportunities to business of improving resource efficiency. Final Report to the European Commission. AMEC Environment \& Infrastructure and Bio Intelligence Service.

[40] European Commission (2020). A New Industrial Strategy for https://www.intereconomics.eu/contents/year/2021/num ber/3/article/the-new-industrial-strategy-for-europe.html.

[41] European Commission (2020). Circular Economy Action Plan. https://ec.europa.eu/environment/strategy/circulareconomy-action-plan_en.

[42] Berry, M.A., Rondinelli, D.A. (1998). Proactive corporate environmental management: A new industrial revolution. Academy of Management Executive, 12(2): 38-50. https://doi.org/10.5465/ame.1998.650515

[43] Padash, A., Bidhendi, G.N., Hoveidi, H., Ardestani, M. (2015). Green strategy management framework towards sustainable development. Bulgarian Chemical Communications, 47: 259-268.

[44] Das, S.C., Singh, R.K. (2016). Green HRM and organizational sustainability: An empirical review. Kegees Journal of Social Science, 8(1-2): 227-236.

[45] Velazquez, L.E., Esquer, J., Munguía, N.E., MoureEraso, R. (2011). Sustainable learning organizations. The Learning Organization, 18(1): 36-44. https://doi.org/10.1108/09696471111095984

[46] Arthur, I., Yamoah, F. (2019). Understanding the role of environmental quality attributes in food-related rural enterprise competitiveness. Journal of Environmental Management, 247(16): 152-160. https://doi.org/10.1016/j.jenvman.2019.06.093

[47] Unal, E., Urbinati, A., Chiaroni, D. (2018). Managerial practices for designing circular economy business models. The case of an Italian SME in the office supply industry. Journal of Manufacturing Technology Management, $\quad 30(3)$ : 561-589. https://doi.org/10.1108/JMTM-02-2018-0061

[48] Akkalatham, W., Taghipour, A. (2021). Proenvironmental behavior model creating circular economy in steel recycling market, empirical study in Thailand. Environmental Challenges, 4: 100112. https://doi.org/10.1016/j.envc.2021.100112

[49] Li, G., Wan, X., Su, S., Su, Y. (2019). How green technological innovation ability influences enterprise competitiveness. Technology in Society, 59(4): 1-11. https://doi.org/10.1016/j.techsoc.2019.04.012

[50] Pratono, A.H., Darmasetiaw, N.K., Yudiarso, A., Jeong, B.G. (2019). Achieving sustainable competitive advantage through green entrepreneurial orientation and market orientation. Emerald Publishing Limited, 32(1): 2-15. https://doi.org/10.1108/BL-10-2018-0045

[51] Apak, S., Atay, E. (2015). Global competitiveness in the EU through green innovation technologies and knowledge production. Procedia - Social and Behavioral Sciences, 181(24): 207-217.

[52] Vargas-Hernández, J.G., López-Lemus, J.A. (2021). Resources and capabilities of SMEs through a circular green economy. International Journal of Circular Economy and Waste Management, 1(1): 1-15.

[53] Tjahjadi, B., Soewarno, N., Hariyati, H., Nafidah, L.N., Kustiningsih, N., Nadyaningrum, V. (2020). The role of green innovation between green market orientation and business performance: Its implication for open innovation. Journal of Open Innovation: Technology, $\begin{array}{llll}\text { Market and Complexity, } 173 \text { : } & \text { 6(4) }\end{array}$ https://doi.org/10.3390/joitmc6040173

[54] A'yuni, Q., Muafi. (2020). Pengaruh Green Intellectual Capital Terhadap Keunggulan Kompetitif Dengan Pemediasi Green Human Resource Management. Jurnal Bisnis: Teori dan Implementasi, 11(2): 81-97.

[55] Huang, C.L., Kung, F.H. (2011). Environmental consciousness and intellectual capital management: Evidence from Taiwan's manufacturing industry. Management Decision, 49(9): 1405-1425. https://doi.org/10.1108/00251741111173916

[56]Firmansyah, A. (2017). Pengaruh green intellectual capital dan manajemen lingkungan organisasi terhadap green organizational identity dan dampaknya terhadap green competitive advantage. Jurnal Substansi, 1(1): 183-219.

[57] Chen, Y.S. (2008). The positive effect of green intellectual capital on competitive advantages of firms. Journal of Business Ethics, 77(3): 271-286.

[58] AnuSingh, L., Shikha, G. (2015). Impact of green human resource factors on environmental performance in manufacturing companies: An empirical evidence. International Journal of Engineering and Management Science, 6(1): 23-30

[59] Yusoff, Y. (2016). For a green human resources management. International Journal of Humanities and Management Sciences, 4(2): 190-194. http://journalsweb.org/siteadmin/upload/P0516208.pdf.

[60] Yusoff, Y. M., Omar, M. K., Kamarudin, M.D. (2019). Practice of green intellectual capital. Evidence from Malaysian manufacturing sector. Malaysia: IOP Conference Series: Materials Science and Engineering, 
1st International Postgraduate Conference on Mechanical Engineering (IPCME2018), UMP Pekan, Pahang, Malaysia, 469: 1-8.

[61] Muafi, M., Norek, T., Siswanti, Y. (2020). The influence of green human capital on business performance: The mediation role of innovation activity. Lecture Notes in Networks and Systems, 194: 1371-1380.

[62] Chen, Y.S., Chang, C.H. (2013). Enhance environmental commitments and green intangible assets toward green competitive advantage: an analysis of structural equation modeling (SEM). Quality \& Quantity, 47(1): 529-543. https://doi.org/10.1007/s11135-011-9535-9

[63] Cabrita, M. d. R. \& Bontis, N., (2008). Intellectual capital and business performance in the Portugege Banking industry. International Journal of Technology Management, 43(1-3): 212-237.

[64] Muafi., Kusumawati, R.A. (2020). Strategic consensus on organizational performance: A contingency approach of organizational culture and isomorphic pressure. Journal of Industrial Engineering and Management, 13(2): 352-370. http://dx.doi.org/10.3926/jiem. 2480

[65] Nemiño, R.C., Gempes, G.P. (2018). The moderating effect of intellectual capital on the relationship between corporate reputation and knowledge sharing of commercial banks. Journal of Administrative and Business Studies, 4(3): 145-155.

[66] Melani, E., Kusuma, A. (2019). Growth opportunity and financial performance: The moderating role of intellectual capital. Proceedings of the 3rd Asia Pacific Management Research Conference (APMRC), Series Advances in Economics, Business and Management Research, pp. 57-60. https://www.atlantispress.com/proceedings/apmrc-19/125943248.

[67] Iqbal, A., Sutrisno, T, Roekhudin, R. (2019). Corporate social responsibility and financial performance: Moderating role of intellectual capital. International
Journal of Social and Local Economic Governance, 5(1): 1-11. https://doi.org/10.21776/ub.ijleg.2019.005.01.1

[68] Hair, J.F., Anderson, R.E., Tathan, R.L., Black W.C. (1995). Multivariate Data Analysis. Fourth Edition. New Jersey: Prentice Hall.

[69] Yusliza, M.Y., Yong, J.Y., Tanveer, M.I., Ramayah, T., Faezah, J.N., Muhammad, Z. (2020). A structural model of the impact of green intellectual capital on sustainable performance. Journal of Cleaner Production, 249: 119334. https://doi.org/10.1016/j.jclepro.2019.119334

[70] Kusuma, H., Muafi, M., Aji, H.M, Sigit, A. (2020). Information and communication technology adoption in small- and medium-sized enterprises: demographic characteristics. Journal of Asian Finance Economics and Business, 7(10): 969-980. http://doi.org/10.13106/jafeb.2020.vol7.no10.969

[71] Firmansyah, M.F., Maulana, H.Z. (2021). Empirical study of E-learning on financial literacy and lifestyle: A Millenial urban generations cased study. International Journal of Engineering, Science \& Information Technology, 1(3): 75-81. http://doi.org/10.52088/ijesty.v1i3.99

[72] Wu, E., Cheng, J.Q., Zhang, J.B. (2019). Study on the environmental education demand and environmental literacy assessment of citizens in sustainable urban construction in Beijing. Sustainability, 12(1): 241. https://doi.org/10.3390/su12010241

[73] Ragas, S.F.P., Tantay, F.M.A., Chua, L.J.C., Sunio, C.M.C. (2017). Green lifestyle moderates GHRM's impact on job performance. International Journal of Productivity and Performance Management, 66(7): 857872. https://doi.org/10.1108/IJPPM-04-2016-0076

[74] Muafi. (2018). Leadership agility, the influence on the organizational learning and organizational innovation and how to reduce imitation orientation. International Journal for Quality Research, 13(2): 467-484. 